\title{
“Les Préludes" by F. Liszt: the Experience of Synaesthetic Analysis
}

\author{
Olga V. Iarosh* \\ Krasnoyarsk State Institute of Arts \\ 22 Lenina Str., Krasnoyarsk, 660049, Russia
}

Received 20.03.2016, received in revised form 19.04.2016, accepted 31.05.2016

The experience of synaesthetic analysis of the symphonic poem "Les préludes" by F. Liszt is represented in the article. This method is based on the study of the phenomenon of synaesthesia, determined by the mechanism of various sensations interaction and synaesthesis as properties of non-verbal thinking, and includes the study of the musical text, as well as analysis of the characteristics of different musical sound modalities. Using it, the peculiarities of the development of deep and psychological plan that do not depend on programmaticity, but are connected with the direct perception of sounding music are revealed in the composition. Synaesthetic analysis gives opportunity to introduce intonation development of the composition, determined by the monothematic principle as a continuous and comprehensive process, full of diverse synaesthetic overtones, based on smooth mutual transitions of contrasting images.

Keywords: synaesthesia, synaesthetic analysis, Romanticism, F. Liszt, symphonic poem, monothematicism.

DOI: 10.17516/1997-1370-2016-9-8-1773-1782.

Research area: culture studies.

Recently, a tendency connected with comprehension of the detailed scope of artistic imagery has become more relevant in musicology. Unlike external - logos and structural side of musical text, an internal plan of expressiveness is determined by the patterns of non-verbal thinking and requires a different approach for its comprehension.

Methods borrowed from phenomenology and psychology - psychosemantics and psychosemiotics that form the direction of psychomusicology in musical science, the focus of which attention is considering intonation processes in music and development of intramusical semantics (the works by E. Kurth, E. Nazaikinsky and V. Medushevsky) are quite productive in this case.

Synaesthetic method developed by N. Koliadenko, based on the works by A. Wellek and B. Galeev, is in the context of this range of problems. This method is based on the study of the phenomena of synaesthesia and synaesthicity determined by the mechanism of interaction of different sensations and includes the analysis of characteristics of different modalities of musical sound into the study of musical text. It provides

(C) Siberian Federal University. All rights reserved

* Corresponding author E-mail address: oliga23k1@yandex.ru 
an opportunity to identify the peculiarities of psychological plan depicted in the composition, which does not depend on programmaticity, but is connected with the direct perception of the musical image. The phenomenon of synaesthicity is like a metaphor, which “... involves not only the transfer of properties, but extension, incorporation, and the connection of phenomena ... that finally allows it to create a generalized image of the world" (Sidneva, 2011: 430).

This approach is of particular relevance in the interpretation of musical compositions, the main content of which is not the external, objective world, but the embodiment of states and experiences. Romanticism is, undoubtedly, one of the artistic movements, precisely distinguished by such attitude to creativity.

Romantic aesthetics that determined the emergence of a new language, new means of expression in music, among which the tendency to the continuity of development connected with confessional and monologue characteristics, typical of the art of Romanticism, as well as a greater degree of unity of different, often sharply contrasting themes and images compared with the art of previous eras, should be mentioned.

Under the influence of the new content in the music of Romanticism, new genres appear. One of these genres is a symphonic poem created by F. Liszt. In the Romanticism aesthetics the idea of synthesis of arts, which was associated with the traditions renovation and progressive tendencies, had a special role. Thus, for example, music and musical forms influenced literary works, their composition, and literature, in turn, influenced musical creativity. This idea was very close to Liszt and his symphonic poems embody the desire to bring together literature and music. Each of them not only tells the story of some events, but through external programmaticity the composer raises profound issues, works for to philosophical generalizations.
This conceptual nature of his compositions required a specific artistic method, and the principle of monothematicism, widely used by the composer, became such a principle ${ }^{1}$. As it is known, monothematicism is "...formation of the whole fundamental thematic material of compositions from one common "source" by variation transformation of the latter" (Mikhailov, 1963: 123). Krauklis writes: "Liszt needed a form ... capacious, multicomponent and flexible ..., in order to comprise complex programme content, musical and philosophical conception reflecting different moments of human life and various aspects of human activities and experiences. Such complexity, however, threatened with garishness and the loss of musical unity. The principle of monothematicism widely developed by Liszt, became the necessary counterbalance" (Krauklis, 1974: 22).

Symphonic poem "Les Préludes" is one of the composer's works, where the artistic method is most consistently embodied. In this article, this composition will be considered from the standpoint of synaesthetic approach, the essence of which consists of three basic procedures: the creation of a holistic visual gestalt of a musical image, musical oscilloscope and synesthetic nuancing of musical sound using the "Dictionary of Polymodal Characteristics²." In our analysis, we refer only to the third procedure by which the fixation of auditory, visual and tactile-kinesthetic parameters and coordinates of sound and space environment is carried out.

"Les Préludes" is one of the most vibrant and life-affirming works of the composer. As it is known, originally musical material of the poem was meant for the overture to men's choruses set on the text of the poem by J. Autran "The Four Elements". But later, on the basis of this material, Liszt created a symphonic poem and connected its content with a poem of another French poet "Les Préludes" by A. de Lamartine. 
Many authors (G. Krauklis, Y. Milstein, et al.) write about non-compliance of this music to its introduced programme, where pessimism about the impermanence of life is expressed. Most likely, Liszt did not set a goal of literal transmission of music content in the accompanying it poetic text, that is, in principle, impossible, since one of the essential qualities of music is its ambiguity, "untranslatability" into the language of verbal definitions and concepts. Any epigraph is only intended to hint at a kind of semantic facet of the composition, to bring to life an association assonant to a composition, specify the direction in which the listener's mind should move. Taking into account the major semantic mismatch (absence of pessimistic conception of human life as a series of preludes to death), the sequence in development of the external content of the poem by A. de Lamartine (the idea of love as life generating principle, the idea of overcoming the obstacles of life, the desire to move away from them and awareness of the inevitability of struggle through which a person is transformed and becomes worthy of life) completely coincides with Liszt's idea. But it is treated by the composer in a different semantic manner.

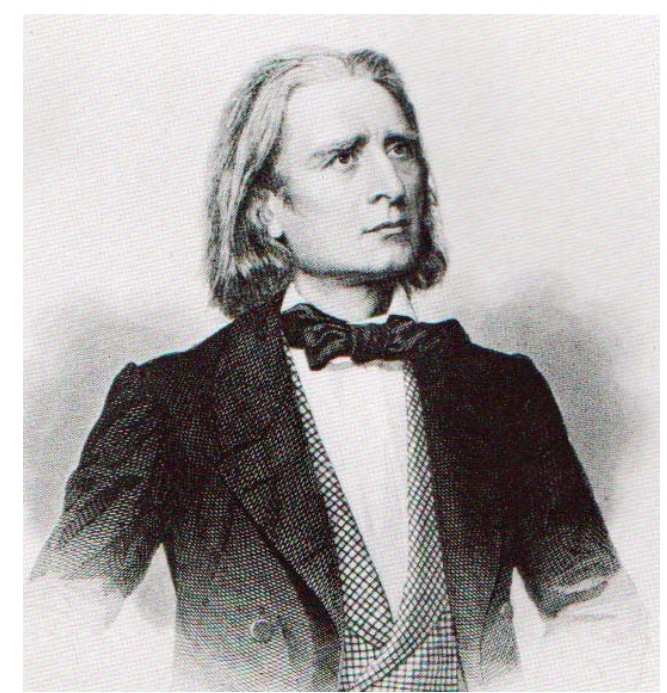

Franz Liszt (1811-1886)
In general - it is a very optimistic and lifeaffirming composition. And its meaning is, of course, not in the pursuit of death and approval of otherworldly ideal, but rather in the idea that love and light is stronger than death, stronger than various ills of life, obstacles and unrest. Perhaps, Liszt primarily had to focus attention not on the figurative, external impression from nature (in the initial version of the poem - the four elements: Earth, Waves, Stars, Winds) but, with the help of A. de Lamartine's poetry, accentuate the moments of psychological conditions.

"Les Préludes", in contrast to some other compositions by Liszt (Sonata in B minor, Faust Symphony and Obermann's Valley), in which the expression of dramatic collision of human soul finds a very strong and emphasized expression, is deprived of such strong dramatism. This symphonic poem contains a more generalized, external origin; it is as if an outside perspective on human life and its various facets. There is a certain detachment; there is no that kind of immersion into the inner state, which we, for example, can observe in Obermann's Valley. And at the same time, these external pictures are simultaneously expressions of certain emotions

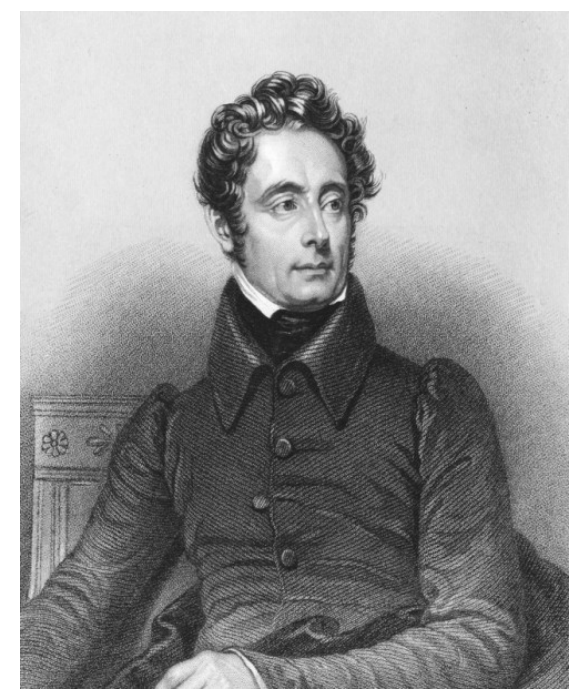

Alphonse de Lamartine (1790-1869) 
and moods. The poem has a lot of subtle, poetic and psychologically truthful moments that embody the transitions from one emotional state to another in details. A. Serov at one time wrote about it: "In the light parts of fantasy it is all clear, beautiful and full of life ... in a serious and somber ones - there is a deep psychological truth" (cited by: (Serov, 1950: 166)). The only dramatic episode in "Les Préludes" is development, where a gloomy image, symbolizing storms and waves of human life appear. But this episode is quickly overcome by the heroic beginning.

Despite remoteness and, in general, sufficient uniformity of image content, this work, based on the principle of monothematicism, can be regarded as an intensive process of intonation formation that in the process of its formation undergoes a series of metamorphoses. From this perspective, the symphonic poem by Liszt is a composition in which the composer wanted to express a deep idea, to show and to reveal it through a series of image transformations. Indispensable connection of this development with the subjective beginning and the personality of the composer himself defined its continuity, a special level of the unity of form, in which everything is subjected to the basic concept approval.

It should be noted that the symphonic poems by Liszt are, as a rule, one-part romantic synthetic forms, based on the continuous development, which combine the features of different classical forms, first of all - the forms of sonata allegro and the features of the sonata symphony cycle. G. Krauklis writes that this work is ".... a composition based on the freely interpreted principles of sonata allegro ... with the entry, an episode in development and mirror reprise of dynamized nature" (Krauklis, 1974: 56).

The symphonic poem begins with the theme of entry (Pattern 1), which at the same time is the source of all the subsequent themes-images of the composition. This theme represents a figurative and emotional convolution or grain, which life serves as a unifying and connecting beginning among the continuous change of relationships. If focus on the programme name "The Four Elements" and A. Serov's definition, pointing to four main images of the poem - love, storm, pastoral and march, it can be assumed that semantic configuration of the generalized figurative unity of the four main facets of human life controls the development. A. Serov wrote, "...one musical idea dominates in the whole fantasy, curving according to the requirements of the poetic and musical task" (Serov, 1950: 569-570). Disclosure of this content happens in the process of development of four organically interconnected elements in a sequential order. The integrity of the symphonic poem lies in formation of the semantic range due to the fact that intonation-invariant undergoes a series of metamorphoses, continuously "twisting" and saturating with the new sensual nuances in each new image embodiment.

\section{Pattern 1}

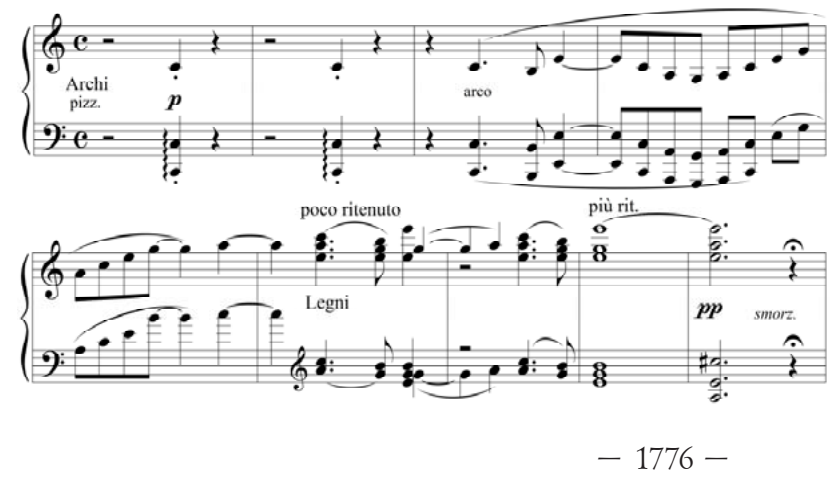


Initial intonation of the entry theme is a romantic motive of an issue, which consists of two intervals that are of great semantic importance for the subsequent development the descending minor second and the ascending fourth. It is important to emphasize that during the second development of this theme from sound $\mathrm{D}$, the perfect fourth is replaced by the diminished one, the moment of distortion of active life-affirming intonation that acquires squeezed and pinched tone takes place. It is on this tone, combined with the chromatic melody, the dramatic part of "development" (the embodiment of the element of storm and struggle) will be built. Thus, the main theme of the composition as a source of vivid and complete development is characterized by the semantic ambiguity of the original, developing from itself intonation grain.

In general, this section represents a picturesque scene; there is an extensive figurative and external origin. From the point of view of extramusical semantics, the composer creates an image of dawn and the rising sun by the means of orchestral sounds: "This melody ... as if symbolizing the awakening of life" (Serov, 1950: 164). From extramusical point of view the theme of entry is an obscure issue that hangs in the air, expressing uncertainty, instability, with gradual clearing. It symbolizes the search, ideas maturing, prelude to the multivalued, comprising four elements image.
This theme will be defined by synaesthetic characteristics. Its deep, sonorous and complete character is created by the timbre of string instruments. Visual characteristics register luminous, raising sound against a dark background, which is gradually enlightened by the upward movement from the lower register to the upper one. The image of a flickering light is embodied by pulsation of high-sounding woodwind chords. The parameter of figurebackground is firstly characterized by the distance of sound, which involves only harps, strings and woodwinds, but gradually, when approaching to the main party in music the effect of increasing the bulk of body sound occurs: horns and trombones join the aforementioned instruments. Kinesthetic characteristics record a warm and complete image; motor and linear characteristics - smoothness and increasing nature of upward movement.

Emergence of the main part (Pattern 2) embodying the image of an integral and powerful man, gives synaesthetic transition to a powerful, rich and vibrant sound in a deploying range of metamorphosis. At the same time there is a change of kinesthetic parameter, expressed in the transition from a smooth wavelike to intense movement. Figurebackground parameter conveys much closer approximation, volume and relief of the theme. Background figurations in stringed instruments create shine, shimmer and volume.

Pattern 2

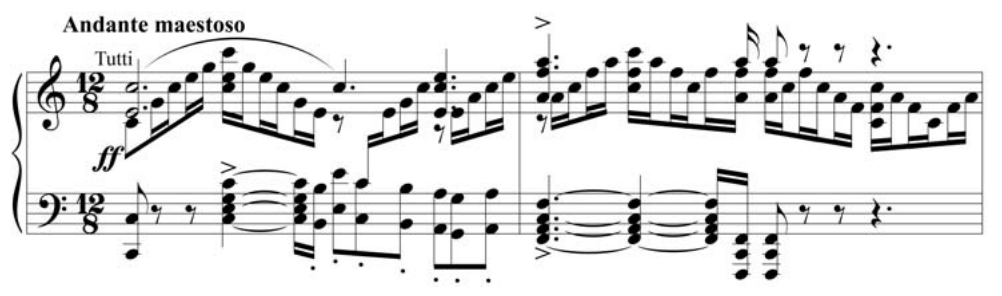


At that, transformed image is not consequential, but is based on interpenetration, an organic transition to a new stage of transformation of the constant core of the main theme. It is noteworthy that within the invariant element, pitch and rhythmic changes indicating its self-development, take place as well. In this regard, it is necessary to emphasize a small, but significant in the expressive relation detail: rhythmic change takes place in the theme presentation, its beginning from the downbeat eliminates uncertainty of the issue and move on the fourth becomes more active as a result of the replacement of eighth value with the sixteenth before the leap. Tirate in the basses gives an important emphasis - the topic acquires confident and heroic character.
The spheres of transitional and subsidiary parties are the embodiment of the element of love. Both of these themes also contain original intonation, but while in the transitional party it manifests itself quite clearly, in the subsidiary party intonation-invariant appears as a part of the whole, appearing not in the beginning of the theme, but in bars 3-4, in a slightly modified form (Patterns 3 and 4). This intonation-invariant is disguised here, as if hidden, but at the same time it retains its identity, keeping the unity of the semantic whole. It is also necessary to emphasize that the subsidiary party sounds in tonality of the major third step (E-dur) in relation to the primary, which, in terms of light and sound synaesthesia creates an effect of bright light. Such ratio of tonalities, as it is known, is very common in Romantic music.

Pattern 3
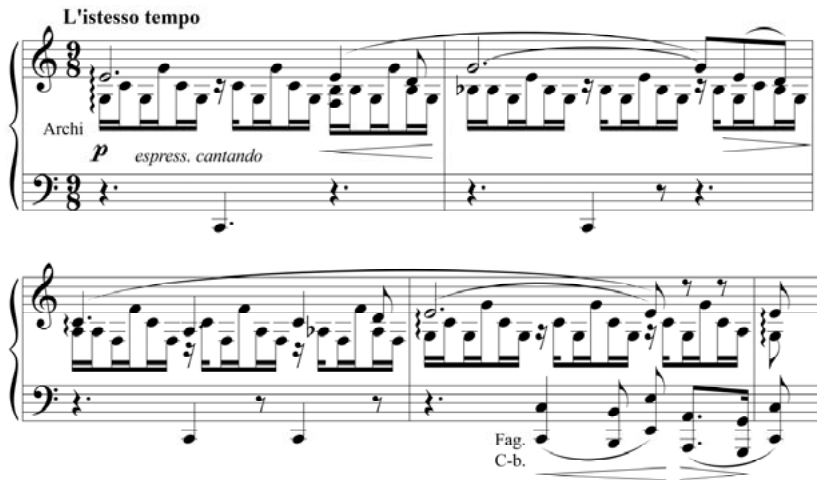

Pattern 4

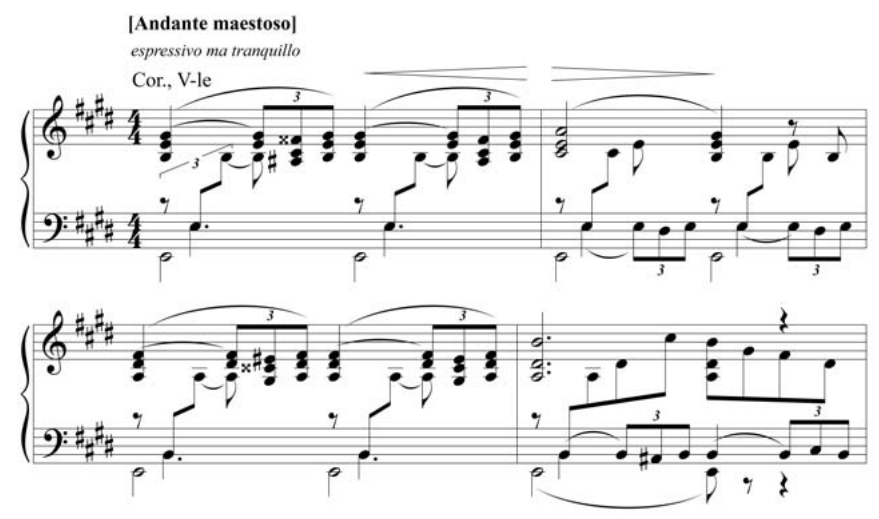


Changes in the manner of presentation regarding tempo, articulation and timbre details radically transform the original intonation. Vividness, activeness, and solemnity of the main party are replaced by the soft, gentle and quiet image. The main synaesthetic features that characterize these themes in general, with their minor differences, are the following: a quiet, muffled, melodious, yet rich sound combined with a larger fading, tarnish and remoteness - in contrast to the vividness of the main party with its advancement to the fore. In addition, it is possible to note a smooth, sliding, "patterned" sound in the transition party and flowing warm, soft, deep and resound in the subsidiary party. Figurebackground parameter is characterized by supporting voice and distant twinkling reproduced by violins' figurations.

The next metamorphosis is embodied in the development representing the element of storm and struggle. This image is based on the same original intonation of the main theme (Pattern 5). As mentioned earlier, this intonation is transformed: ascending tempo in the perfect fourth changes to the diminished fifth and, due to this, the theme acquires alert and anxious character.

\section{Pattern 5}

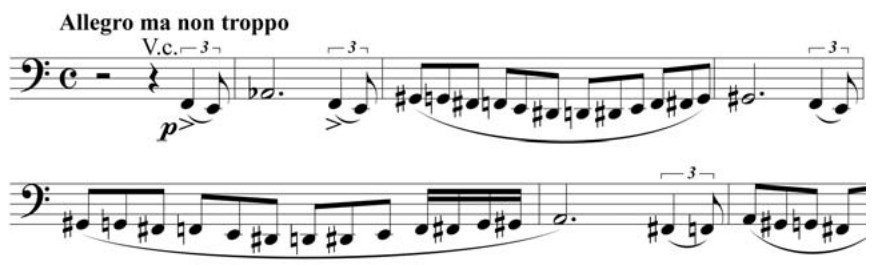

The sphere of development in terms of sound representation is in a deep contrast to the just faded away subsidiary party. Synaesthetic markers detect quiet and rustling sounds, which ominous character is determined by the low register and the cellos' timbre; as well as dark, "black and grey" cold and prickly sound; whirl-like, impulsive and sliding motion. The first section of the development is almost entirely based on the background material, except for the dotted intonation initially executed by clarinet. In further development the transformed motive of the issue becomes heroic and, at the same time, due to distortion of the main intonation, threatening tone, it sounds very powerful in trumpets and trombones, accompanied by sharp staccato chords of the orchestra, tutti and tirates in cellos and double basses, reminiscent of the first appearance of the main party theme, in this case related to the embodiment of the image of struggle.

It should also be noted that the invariant element of the main theme, transformed in the main party, at a certain moment appears here in the original variant that is, at an interval of the perfect fourth, symbolizing a turning point in its development. Starting from this moment the development consolidates active and defeating beginning. Furthermore, another intonation of the original motive - minor second that in this case is represented not in the ascending, but descending variant, plays an important role in

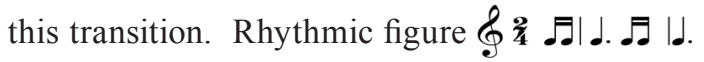
is of certain expressive importance, it sounds first in the brass (Pattern 6) and then in violins, embodying the heroic and consolidating nature of the overall sound. 


\section{Pattern 6}

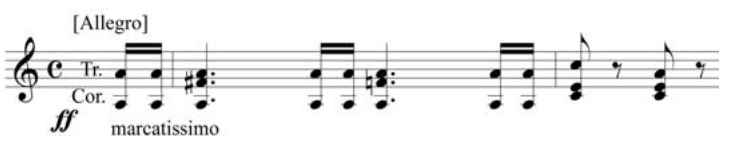

Development of the forming series, organically linked in the semantic configuration of the leading theme of the four elements, leads to a new metamorphosis. After the development of the linking part theme, in sharp contrast to the previous image the theme of the episode appears again (Pattern 7), which represents the light elements of nature and pastoral images. Its external sensual clarity and specificity is confirmed by synaesthetic characteristics, among which visual enlightenment, pastel, serene, muted and soft colors are considered significant; figure-background relationships reveal spatiality (embodied through the roll call of shepherds theme in different instruments); gravitational coordinate registers lightness; tactile and temperature softness and warmth. Internal self-development of the invariant element of the original theme in this section consists in transformation the original intonation underlying this theme, the fourth and the second switch places and are represented in the ascending variant. Activeness of the descending quart is softened by the fact that intonation in this case is upbeat.

\section{Pattern 7}
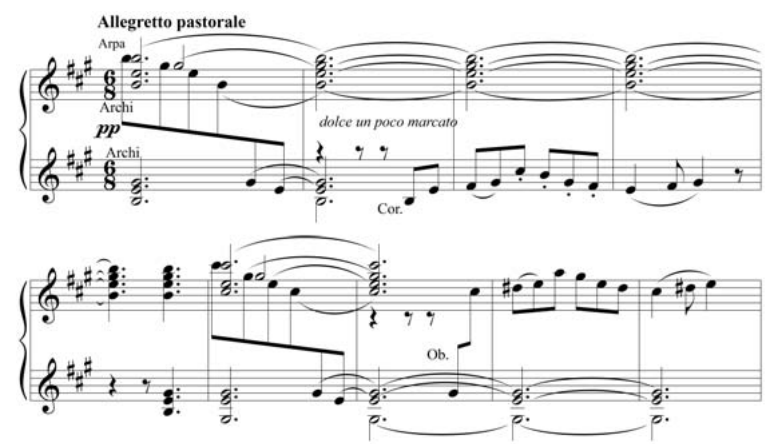

Return of the subsidiary party in the reprise, which sounds in the main tonality - $\mathrm{C}$ major, represents a compound of the elements of nature and love. Here, it obtains different semantic overtones, compared to the original composition. If this theme in the exposition was an embodiment of the lofty ideal, in the reprise it embodies a certain psychological state associated with the lyrical sphere, it sounds as if more "realistic", complete and impulsive. First, it is represented in the party of violins, then the flute and the horns. Gradually, the image is becoming heroic - the tutti orchestra performs the theme, it acquires pompous, active, strong-willed and affirming character.

The fourth element of the semantic range of the original tone, defined by A. Serov as the march, is represented by the transformed theme of the main party. This theme, firstly presented in the amended version, but then sounding in the exposition as well, gradually, in the general wave of the extended heroically victorious assertion acquires other connotations: it is perceived not only as an abstract heroic image (as it was at the beginning), but as a result of the whole development, as a victory over obstacles and as 
an approval of light and life. Serov denoted this boundary through the name of the genre - march, but it is possible to assume that this element combines all the rest, implementing a positive, life-affirming conception of the poem.

In conclusion, it should be noted that the continuity of the thematic development in this composition is highlighted by pulsation, created by the development of the theme of linking part between all the themes-metamorphosis. In addition, spatial effect of proximity-remoteness pulsates in the musical text: the theme of entry embodies the image of approaching from afar, the main part is a powerful sound at the foreground, linking and subsidiary parties are suspension to the background; development represents the close-up and the following sound of the linking party and the episode is perceived as a spatial detachment; the reprise is a wave of sonority intensification and dynamics increase, in which the effect of sound array approximation is expressed. The moment of pulsation is emphasized by the change in the nature of these themes, embodying in the alternation of soft and active sound.

Thus, synaesthetic method in this composition allowed revealing psychological nuances of musical images and representing intonation development as an extensive, filled with diverse synaesthetic overtones establishment.

$1 \quad$ See also: (Iarosh, 5(43) (2014))

2 For more on synaesthetic method see [1], [2]

\section{References}

Iarosh, O. (2014). Simfonicheskaia poema "Tasso" F. Lista: sinesteticheskaia interpretatsiia teksta. [The Symphonic Poem "Tasso" by F. Liszt: Sinesthetic Interpretation of the Text], In Istoricheskie, filosofskie, politicheskie i iuridicheskie nauki, kul'turologiia i iskusstvovedenie. Voprosy teorii $i$ praktiki. [Historical, Philosophical, Political and Law Sciences, Cultorology and Study of Art. Issues of Theory and Practice], 5(43), II, 213-217.

Koliadenko, N. (2005). Sinestetichnost'muzykal'no-khudozhestvennogo soznaniia (na materiale iskusstva XX veka) [Synaestheticism of Musical and Artistic Consciousness (Based on the 20 ${ }^{\text {th }}$ Century Art)]. Novosibirsk, $392 \mathrm{p}$.

Koliadenko, N. (2008). Sinesteticheskaia interpretatsiia muzykal'nykh tekstov [Synaesthetic Interpretation of Musical Texts], In Sinesteziia: Sodruzhestvo chuvstv i sintez iskusstv. Materialy mezhdunarodnoi nauchno-prakticheskoi konferentsii [Synaesthesia: The Union of Senses and Synthesis of Arts. Materials of the Scientific and Practical Conference]. Kazan', 183-188.

Krauklis, G. (1974). Simfonicheskie poemy F. Lista [The Symphonic Poems by F. Liszt]. Moscow, $141 \mathrm{p}$.

Mikhailov, M. (1963). O tematicheskom ob"edinenii sonatno-simfonicheskogo tsikla. [On Thematic Combining of the Sonata and Symphonic Cycle], In Voprosy teorii i estetiki muzyki [Issues of Theory and Aesthetics of Music]. Leningrad, (2), 121-145.

Serov, A. (1974). Izbrannye stat'i [Selected articles]. Moscow, (1), 626 p.

Sidneva, T. (2011). Muzyka kak metafora Serebrianogo veka [Music as a Metaphor of the Silver Age], In Voprosy kul'turologii [Culturology Issues], (7), 42-48. 


\section{«Прелюды» Ф. Листа: \\ опыт синестетического анализа}

O.В. Ярош

Красноярский государственный институт искусств Россия, 660049, Красноярск, ул. Ленина, 22

В статье предпринимается опыт синестетического анализа симфонической поэмы Ф. Листа «Прелюды». Данный метод основывается на изучении феномена синестезии, обусловленного механизмом взаимодействия различных ощущцений, и синестетичности как свойства невербального мышления и включает в исследование музыкального текста анализ разномодальныххарактеристикмузыкального звучания. Сего помощью в указанном сочинении выявляются особенности развития глубинного, психологического плана, которые не зависят от программности, но связаны с непосредственным восприятием звучащей музыки. Синестетический анализ позволяет представить интонационное развитие произведения, обусловленное монотематическим принципом, как непрерывный, объемный, наполненный многообразными синестетическими обертонами процесс, основанный на плавных взаимопереходах контрастных образов.

Ключевые слова: синестезия, синестетический анализ, романтизм, Ф. Лист, симфоническая поэма, монотематизм.

Научная спещиальность: 24.00.00 - культурология. 